\title{
外壁面に発生する藻類の同定および藻類污染方法の検討
}

\author{
建築物の外壁面における藻類污染に関する研究
}

\section{IDENTIFICATION OF FRESH-WATER ALGAE OF EXTERNAL BUILDING WALLS AND STUDY ON AN EVALUATION METHOD FOR THE SOILING BY FRESH-WATER ALGAE}

Study on the soiling by fresh-water algae of external building walls

\author{
辻本吉寛*, 大羽伸和**, 須藤哲 也*** \\ Yoshihiro TSUJIMOTO, Nobukazu OHBA and Tetsuya SUDOH
}

\begin{abstract}
We performed a series of studies to designate the algae which is the main factor of these soiling, and to establish methods which can evaluate materials in regard to soiling of external walls.

The following results became clear after this investigation. Soiling of external walls is usually caused by the fresh-water algae named Protococcus Viridis Agardh. We can evaluate the degree of growth of algae on the external materials by applying two independent tests, one is outdoor exporsure test and the other one is indoor accelerated test in which we diviced techniques for supplying moisture, nutriment and algae to samples.
\end{abstract}

Keywords : fresh-water algae, Protococcus Viridis Agardh, soiling, external walls 藻類, プロトコックス属, 污染, 外壁

\section{1. はじめに}

建築物の外壁面の污染のひとつに，藻類が発生するた めに緑色～暗緑色に污れるという現象がある。この現象 は近年, 外壁材料の高級化志向にともなう表面形状の複 雑化により目立つようになってきた。

これまでに污染全体の分類および発生のメカニズムに ついては仕入らの研究文1,21があり，塵埃などによる污染 については橘高らの一連の研究坟1,41,51において污染程度 の定量化方法ならびに屋外暴露および污染促進試験装置 を用いた評価方法が提案されている。また，徽による污 染については大島らの研究刘がある。

一方，富栄養化や魚網など水中での藻類污染の評価方 法や環境因子については多くの研究文11,8)がある。

しかし, 著者らが知る限りにおいて, 外壁面での藻類 污染について藻類を特定し評価方法を提案しているもの はない。

本研究の目的は, 外壁面の污染の原因となる藻類を特 定し，藻類による污染に関する外壁材料の評価方法を確 立することにある。

\section{2. 藻類の特定}

\section{1 試験概要}

まず，外壁面の污染原因となる藻類を特定すること， 並びに，特定した藻類を促進試験に供試することを目的 として，実際の外壁材料から採取した藻類の分離・培養 および同定を行った。

\section{(1) 採 取}

表一 1 に示す個所の一般住宅の外壁面から藻類と思わ れる部分を採取した。No.1〜4は外壁面の中央部分で あり，No. 5 だけは水切りに接する（水分を含んでいる 時間が長いと思われる）部分であった。

\section{表-1＼cjkstart藻類採取個所}

\begin{tabular}{|c|c|c|}
\hline No & 所 & 下地材。仕上睉材の種類 \\
\hline 1 & 山口県山口市 & 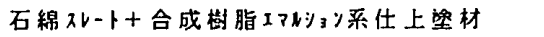 \\
\hline 2 & 湴賀県栗太郡 & モルタル吹付（無染装） \\
\hline 3 & " & 玉 \\
\hline 4 & 静岡県小笠郡 & 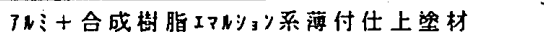 \\
\hline 5 & 京都付舞轱市 & 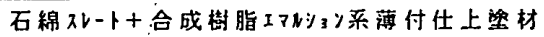 \\
\hline
\end{tabular}

* 積水ハウス総合住宅研究所

** 積水ハウス総合住宅研究所

*** 積水ハウス総合住宅研究所
Comprehensive Housing R \& D Institute, Sekisui House, Ltd. Comprehensive Housing R \& D Institute, Sekisui House, Ltd Comprehensive Housing R \& D Institute, Sekisui House, Ltd. 


\section{（2）分離・培養}

外壁面から採取した藻類と思われる部分を以下の手順 に従い分離・培養を行った。

(1) 減菌水中に採取した藻類を入れ 1 細胞ずつになるま で十分に㩖汼し，ペニシリンとストレプトマイシンを 各々 $0.01 \%$ 加えたのち 3 時間静置した。

(2) 遠心分離器を用いて，攪汼・バクテリアなどとの分 離・浮遊物の除去・減菌水の注入を 5 回繰り返した。

(3) ある程度分離された藻類細胞群をスライドグラス上 に取り，微動装置を用い顕微解剖機（写真一1）に取り 付けた極微スポイドを操作して，元気な藻類細胞を 1 個 ずつ吸い取った。

(4) 採取個所ごとに，シャーレ中の寒天培地 ${ }^{211} に$ 藻類

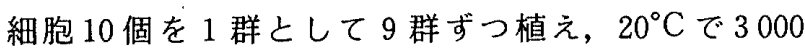
ルックスの蛍光灯照射 14 時間と暗黒 10 時間を繰り返す ようにした培養室で 3 週間静置した。その間, 数日ごと に顥微鏡で状況を観察して，バクテリアや徽の発生が認 められる部分や藻類細胞が死堿している部分の寒天をく りぬいて除去した。

（5) 増殖した藻類細胞群を少量の滅菌水に分散させ，再 度分離・植え付け・培養を行った。

(6) 順調に増殖した藻類細胞群のみを培養液 ${ }^{22}$ に入れ

(4)の条件で培養を継続した。

(7) 培養した藻類細胞について, 透過イマルスキー式微 分干渉顕微鏡を用いて観察を行った。

\section{2 結 果}

外壁面の一般部から採取し分離・培養した 4 個所の藻 類について影微鏡観察と文献 9，10）の比較検討を行っ た結果，いすれれも写真一 2 と図一 1 に示すように「Protococcus Viridis Agardh ${ }^{\text {注31 }}$ : 緑藻植物門ヒビミドロ目 プロトコックス科プロトコックス属」(以下, プロトコッ クス属という。)であることがわかった。

同様にして，外壁下端部の絶えず水分を含んでいた部

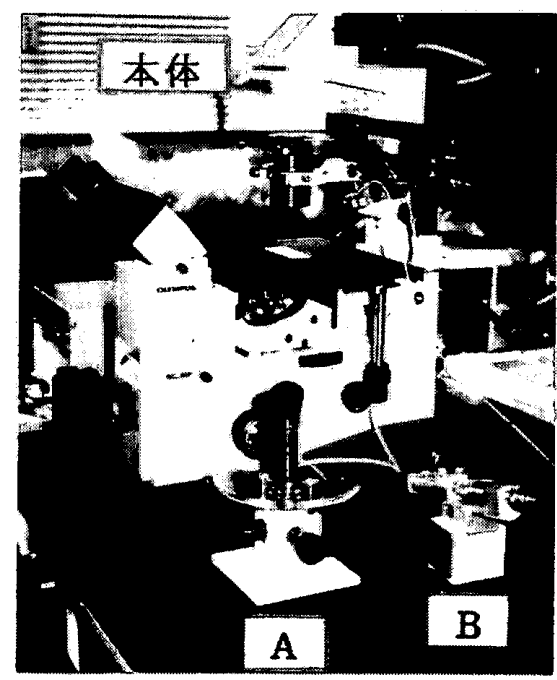

A：極微スポイド 微動装置

B：細胞吸取装置

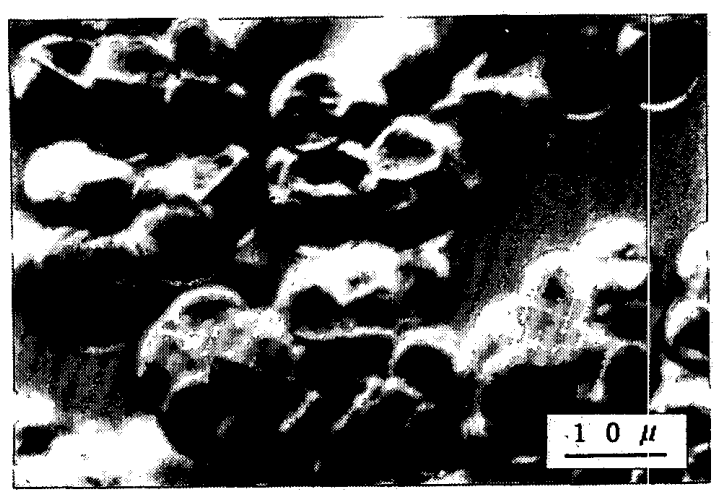

写真一2 分離培養後の藻類の顕微鏡写真

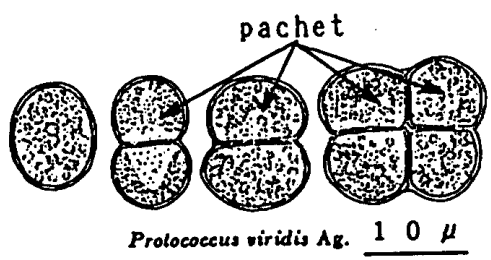

図一1 文献 9）に記載されたプロトコックス㞾

分から採取した藻類は「Phormidium Foverolatum：藍 藻類ネンジュモ目ユレモ亜目ユレモ科フォルミジウム 属」であることがわかった。

\section{3 藻類の発生要因}

プロトコックス属の発生に影響を及ぼす要因として は, プロトコックス属が分布していることと, 温度・水 分・栄養分など生育するための環境要因が考えられる。 そこで，これらの要因について簡単な追加実験などの結 果をもとに考察する。

\section{（1）プロトコックス属の分布}

プロトコックス属はもっともポピュラーな気生藻類の ひとつで，日本中に分布しているといわれている文10)。

\section{(2) 温度}

プロトコックス属の温度に対する適応性を確認するた めに, 所定の温度に保った培養液・培養室の中て藻類細 胞を前述と同様に照射・暗黒を繰り返しながら 72 時間 培養を行った。その結果, $20 \sim 31^{\circ} \mathrm{C}$ までは順調に增殖

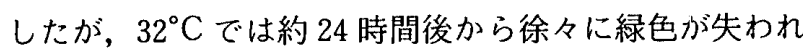
72 時間でほとんど死滅した。つまり，プロトコックス 属の生育適応限界は $31^{\circ} \mathrm{C}$ である。したがって，温暖な 地域の直射日光が当たらない北向きなどの外壁面はプロ トコックス属の生育に適していると思われる。

(3) 水分

プロトコックス属は湿気を含んだ空気から水分を吸収 する能力が大きく空気中で生育・増殖できる気生藻類の 一つである対。したがって，湿度の高い日本ではごこ でも発生し，その中でも降水量が多く緑などが多い地域 の外壁面が最も生育しやすいと思われる。しかし，あま り長く水と接するような部位では，プロトコックス属に 
かわって藍藻類などの他の藻類が生育し, これらの藻類 によってプロトコックス属の生䏍が阻害されると思われ る。

\section{(4) 栄養分}

プロトコックス属をはじめ藻類は, クロロフィルを持 ち光合成により有機物を生成する自栄養生物であるが， 外部から栄養分が供給されるとより活発に增殖する。栄 養分の供給源としては, 硝酸塩・アンモニ゙ウム塩やりん 酸塩の形で雨水や塵埃に含まれている窒素 $(\mathrm{N}) \cdot り ん$

(P) がある文i!

これらの要因をまとめると，日当たりの悪い外壁面は プロトコックス属にとって非常に発生・生育しやすい環 境と思われる。このことと今回外壁面の中央部分から採 取した藻類がいずれもプロトコックス属であったことか ら，今回藻類を採取した地域では建築物の外壁面におい て污染の原因となる主な藻類はプロトコックス属である と判断できる。

\section{3. 屋外暴露予備試験}

\section{1 試験概要}

滋賀県・大阪府などの団地を調查した結果，施工後 3 －5年以降の住宅で藻類の発生が認められた。したがっ て，単に暴露するだけであれば，藻類が発生するまでに 同等の期間を要すると思われる。そこで，自然環境に加 えて水分と栄養分を人為的に与えて発生までの期間を短 縮化した屋外暴露方法を考案するための予備試験を実施 した。

\section{（1）試 料}

試料としては，表一2 に示す塗料系や表面形状などの 異なる 9 種類の外壁仕上塗材（下地材：アルミ）を用い た。試料のサイズは $250 \times 400 \mathrm{~mm}, \mathrm{~N}$ 数は 2 とした。

\section{表一2 試料／屋外暴露予備試験}

\begin{tabular}{|c|c|c|c|c|c|}
\hline 梁料 & $\begin{array}{l}\text { 表面 } \\
\text { 形状 }\end{array}$ & $\begin{array}{l}\text { 淕装 } \\
\text { 回数 }\end{array}$ & $\begin{array}{l}\text { 淕料 } \\
x-力-\end{array}$ & $\begin{array}{l}\text { 防藻 } \\
\text {. 剂 }\end{array}$ & 略 \\
\hline $\mathrm{E}$ & $F$ & 1 & $\mathrm{~K}$ & 0 & $\mathrm{EF} 1 \mathrm{~K} 0$ \\
\hline E & $\mathbf{R}$ & 1 & K & 0 & $\mathrm{E} R 1 \mathrm{~K} 0$ \\
\hline $\mathrm{E}$ & $\mathbf{R}$ & 2 & K & 0 & $\mathrm{ER} 2 \mathrm{~K} 0$ \\
\hline E & $\mathbf{R}$ & 2 & $\mathrm{~N}$ & 0 & $\mathrm{ER} 2 \mathrm{~N} 0$ \\
\hline E & $\mathbf{R}$ & 2 & D & 0 & $\mathrm{ER} 2 \mathrm{D} 0$ \\
\hline $\mathrm{E}$ & $\mathbf{R}$ & 2 & D & A & E R 2 D A \\
\hline $\mathrm{E}$ & $\mathrm{R}$ & 2 & D & B & $\mathrm{ER} 2 \mathrm{DB}$ \\
\hline A & $\mathbf{R}$ & 2 & K & 0 & A R $2 \mathrm{~K} 0$ \\
\hline U & $\mathbf{R}$ & 2 & $\mathrm{~K}$ & 0 & $\mathrm{UR} 2 \mathrm{~K} 0$ \\
\hline
\end{tabular}

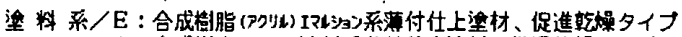

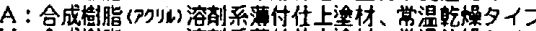
表面形状 $/ F:$ : 合成楆脂 $\mathrm{R}:$ :リン

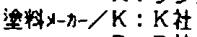
$\mathrm{D}: \mathrm{D}$ 社 $\mathrm{N}: \mathrm{N}$ 社
等装回数 $/ 1: 1$ 回 $2: 2$ 回 $A:$ ビリジン系

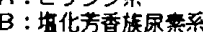

\section{（2）武験方法}

(1) 試料の取付：試料は北向き・横一列・垂直にして, フェンスに固定した木製の試料台に釘で取り付けた。

・設置位置 地上から $800 \mathrm{~mm}$ (下端部)

(2) 水分の供給：塩素系殺菌剂や鉄分を除去し雨水に近 ゔけるために，水道水を活性炭ろ過器を通したのち，10 $\mathrm{mm}$ 間隔に直径 $2 \mathrm{~mm}$ の穴をあけた塩化ビニル管から散 水した。なお，散水時間は 24 時間夕イマーで制御した。

- 散水時間 30 分 $/ 6$ 時間

・散水量 1 枚あたり $8 \pm 1 l /$ 分

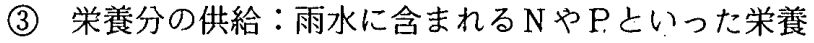
分を人為的に与えるために，( $\left.\mathrm{NH}_{4}\right)_{2} \mathrm{HPO}_{4}$ を溶かした水 溶液を1.日1回洗浄瓶を用いて散布した。藻類の増殖に は $\mathrm{P}$ 濃度 1〜 $5 \mathrm{ppm}, \mathrm{N}$ 濃度 5〜10 ppm が適していると いわれており文1),7，散水や雨水によりすぐに希釈される ことを考慮して，P濃度 $10 \mathrm{ppm} ， \mathrm{~N}$ 濃度 $18 \mathrm{ppm}$ に調整 した。供給量は 1 枚あたり約 $20 \mathrm{ml}$ (試料全体を濡らす 程度）とした。

(4) 暴露期間：1988 年 3 月 1 日 10 月 31 日／ 8 力月

(5) 暴露地：滋賀県栗太郡栗東町

(6) 暴露環境注4):

- 平均温度 $18.1^{\circ} \mathrm{C}$

- 平均湿度 $75 \% \mathrm{R} . \mathrm{H}$.

- 降水量（合計） $1477 \mathrm{~mm}$

\section{2 結果および考察}

\section{（1）藻類の発生状況}

試験結果を表一 3 に示す。なお，藻類発生ランクとは 8 力月後の発生状況を外観より判断して0－3に区分し た藻類の発生しやすさのランクである。また，下端部と は試料台の下枠に接している試料の端部付近の, 水に接 している時間が非常に長い部分を指す。

2 力月後ぐらいから徐々に藻類が発生し，8 力月後で は防藻剤を含まない試料すべてに藻類が発生した。

塗料系としては，エマルション系強制乾燥夕イプのラ

\section{表一-3 屋外暴簬予借試験結果}

\begin{tabular}{|c|c|}
\hline 略 号 & $\begin{array}{l}\text { 漅類発生 } \\
\text { ランク }\end{array}$ \\
\hline$E F 1 \mathrm{~K} 0$ & 1 \\
\hline E R $1 \mathrm{~K} 0$ & 3 \\
\hline $\mathrm{E} R 2 \mathrm{~K} 0$ & 3. \\
\hline E R $2 N 0$ & 2 \\
\hline E R 2 D 0 & 3 \\
\hline E R $2 \mathrm{DA}$ & 3 \\
\hline E R 2 D B & 0 \\
\hline $\mathrm{A} \mathrm{R} 2 \mathrm{~K} 0$ & 1 \\
\hline $\mathrm{U} R 2 \mathrm{~K} 0$ & $\therefore 1$ \\
\hline
\end{tabular}

く藻類発生ランク> 0 : 試料に藻類の発生 が認められない。 1 : 試料の下端部のみ に莯類の発生が認 められる。

2 : 試料面積の $1 / 3$ 末満に葙類の発生 が認められる。

3 : 武料面積の $1 / 3$ 以上に藻類の発生 が認められた。 
ンクが溶剤系常温乾燥タイプのそれに比べて大きかっ た。表面形状としては，リシンのランクがフラットのそ れに比べて大きかった。また, 塗料メ一カーでの差も若 干認められた。これらの差が生じた原因は, 水分・栄養 分が供給されたときの保持しやすさの違いによるものと 思われる。

試料の中で藻類がまったく発生しなかったのが防藻㓮 を混入したER $2 \mathrm{DB}$ のみであり, 防藻㓮には藻類の発 生に対して大きな抑制効果が認められた。ただし，ER 2 DA では抑制効果がほとんどに認められず，防藻剛の 種類によりその程度が大きく異なった。

\section{（2）試験方法の妥当性および問題点}

予備試験としては「藻類の発生しやすさ」を評価しう るデータが得られ，人為的に加えた水分や栄養分による 促進効果も認められたことから，今回の方法は基本的に は妥当な方法であったと考えられる。

しかし，以下の改善すべき問題点が見つかった。

(1) 栄養分の供給を人手に頼るため, 休日などの関係で 安定した供給ができなかった。

(2) 散水量が多すぎたために，十分に散水された部分よ りその境界付近のほうが先に藻類の発生がみられた。

(3) 活性炭ろ過器だけでは完全に水道管の錆を除去しき れなかった。

\section{4. 屋外暴露試験}

\section{1 試験概要}

予備試験の問題点を改善し評価方法を確立することを 目的亡して, 再度屋外暴露試験を行い, 防藻剤を混入し た外壁仕上塗材を含め藻類の污染に関する外壁材料の評 価を試みた。

\section{（1）試 料}

試料としては，表一 4 に示す塗料メ一カ一・樹脂系お よび防藻剤の異なる 10 種類の外壁仕上塗材（下地材： 石綿スレート）にコンクリートブロックなどの一般建材 を加えた 16 種類の外壁材料・外装材料を用いた。試料 のサイズは $150 \times 400 \mathrm{~mm}, \mathrm{~N}$ 数は 2 とした。

\section{(2) 試験方法}

(1) 試料の取付：試料は，図一 2 に示すように水分が供 給されやすいようにわずかに傾斜させ（勾配：9/10)， 北向き・横一列にして，フェンスに固定した塩化ビニル 製の試料台にパッキング材を詰め込んで取り付けた。

・設置位置 地上から $800 \mathrm{~mm}$ (下端部)

(2) 水分・栄養分の供給：雨水に近い状態で均一に水 分・栄養分を供給するために散水方法などを変更した。 まず活性炭ろ過器およびミクロンフィルターを通した水 道水を眝水タンクに，( $\left.\mathrm{NH}_{4}\right)_{2} \mathrm{HPO}_{4}$ を溶かした液を薬液 タンクに貯めた。定量ポンプを用いてそれらを混合しな がら散水量が均一になるように枝分かれさせた壏化ビニ
表-4 試料／屋外暴露試験

\begin{tabular}{|c|c|c|c|c|c|}
\hline $\begin{array}{l}\text { 塣料 } \\
\text { 系 }\end{array}$ & $\begin{array}{l}\text { 表面 } \\
\text { 形状 }\end{array}$ & $\begin{array}{l}\text { 梁装 } \\
\text { 回数 }\end{array}$ & $\begin{array}{l}\text { 準料 } \\
x-x-\end{array}$ & $\begin{array}{c}\text { 防藻 } \\
\text { 剂 }\end{array}$ & $\begin{array}{l}\text { 略 号 } \\
\text { 名 称 }\end{array}$ \\
\hline E & $\mathbf{R}$ & 2 & $\mathbf{K}$ & 0 & $\mathrm{E} \mathrm{R} 2 \mathrm{~K} 0$ \\
\hline E & $\mathbf{R}$ & 2 & K & B & E R $2 \mathrm{~K} \mathrm{~B}$ \\
\hline E & $\mathbf{R}$ & 2 & $\mathrm{~K}$ & $\mathrm{C}$ & E R $2 \mathrm{~K} \mathrm{C}$ \\
\hline E & $\mathbf{R}$ & 2 & $\mathrm{~N}$ & $\mathrm{~B}$ & E R 2 N B \\
\hline E & $\mathrm{R}$ & 2 & $\mathrm{~N}$ & D & ER 2 ND \\
\hline $\mathrm{E}$ & $\mathrm{R}$ & 2 & $\mathrm{D}$ & B & E R $2 \mathrm{D} B$ \\
\hline F & $\mathrm{R}$ & 3 & W & A & F R $3 \mathrm{WA}$ \\
\hline $\mathrm{F}$ & $\mathbf{R}$ & 3 & W & B & $\mathrm{FR} 3 \mathrm{~W} \mathrm{~B}$ \\
\hline$S$ & $\mathbf{R}$ & 3 & I & B & $\begin{array}{lllll}S & R & 3 & \text { I } & B\end{array}$ \\
\hline S & $\mathbf{R}$ & 3 & $\mathbf{I}$ & E & $S R 3$ I E \\
\hline \multicolumn{5}{|c|}{ 杉板 $12 \mathrm{~mm}$ 厚 } & 杉 板 \\
\hline \multicolumn{5}{|c|}{ コンクリートブロック } & コンクリートプロ品ク \\
\hline \multicolumn{5}{|c|}{ 塩ビ鋼板（N S 社） } & 塩ビ龬板 \\
\hline \multicolumn{5}{|c|}{ カラー鉄板 (N S 社) } & カラー鉄板 \\
\hline \multicolumn{5}{|c|}{ 針葉樹合板（ $\mathrm{H}$ 社） } & 釬葉樹合板 \\
\hline \multicolumn{5}{|c|}{ 石綿スレート（NO社） } & 石綿スレー \\
\hline
\end{tabular}

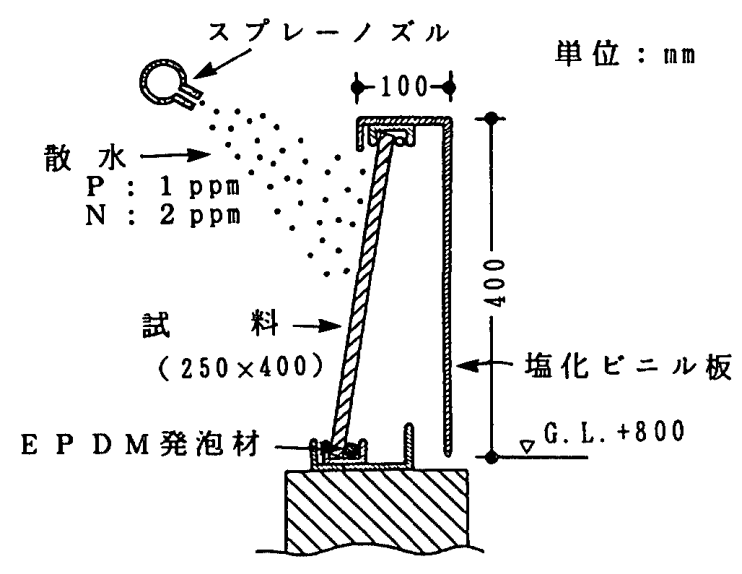

図一2 スプレーノズルによる散水

ルの配管に送り，図一 2 に示すように配管に取り付けた スプレーノズルから婯状にして試料に散水した。栄養分 を散水中に混入するため，P濃度および $\mathrm{N}$ 濃度は前回よ り薄くそれぞれ 1 および $2 \mathrm{ppm}$ になるように調整した。 散水時間・散水量は前回より小さくした。なお, 散水時 間は 24 時間タイマーで制御し，タンクや配管內での藻 類の発生防止やスプレーノズルの詰まり防止のため，遮 光および定期的な点検を行った。

- 散水時間 5 分 $/ 6$ 時間

・散水量 1 枚あたり $160 \pm 10 \mathrm{ml} /$ 分 
(3) 暴露期間：1989 年 4 月 25 日 9 月 25 日 $/ 5$ 力月

(4) 暴露地: 滋賀県栗太郡栗東町下鈎

(5) 暴露環境注4):

- 平均温度. $21.9^{\circ} \mathrm{C}$

- 平均湿度 $76 \% \mathrm{R} . \mathrm{H}$.

- 降水量（合計） $994 \mathrm{~mm}$

4.2 結果および考察

(1) 藻類の発生状況

藻類の発生状況を表一 5 に示す。発生するまでの期間 が予備試験の約 $1 / 2$ に短縮され，1 力月後ぐらいから 徐々に藻類が発生しはじめ, 5 力月では防藻剮を含まな い試料すべてに藻類が発生した。また，ばらつきも小さ かった。

予備試験と同様に, 防藻剤には藻類の発生に対して大 きな抑制効果が認められるが，防藻剤の種類などにより その程度が大きく異なった。これは，一概に防藻垖といっ ても元々防徽剤や除草剤などに使われていた薬㓮を改質 させていて全く性質が異なるうえ塗料への混入方法も異 なるため, プロトコックス属などの特定の藻類に対する 効果およびその効果の持続性の点で大きな差となって表 れたと思われる。なお，塗料系なよ゙による差は認められ なかったが，これは塗料系などによる差よりも防藻檦の 影響が大きいためと思われる。

\section{（2）試験方法の妥当性}

今回の屋外暴露試験において藻類の発生した試料の中 から代表的なものについて，2. 藻類の特定と同じ方法 にて藻類の採取・分離・培養および同定を行った。その 結果, 表一 6 に示すように仕上塗材・材・コンクリー

\section{表一5 屋外暴露試験結果}

\begin{tabular}{|c|c|}
\hline $\begin{array}{l}\text { 略 号 } \\
\text { 名 称 }\end{array}$ & $\begin{array}{c}\text { 藻類発生 } \\
\text { ランク }\end{array}$ \\
\hline E R $2 \mathrm{~K} 0$ & 3 \\
\hline E R $2 \mathrm{~K} \mathrm{~B}$ & 1 \\
\hline $\mathrm{E} \mathrm{R} 2 \mathrm{~K} \mathrm{C}$ & 1 \\
\hline E R $2 \mathrm{NB}$ & 0 \\
\hline E R $2 \mathrm{ND}$ & 2 \\
\hline E R $2 \mathrm{D} \mathrm{B}$ & 0 \\
\hline F R 3 W A & 3 \\
\hline $\mathrm{FR} 3 \mathrm{WB}$ & 0 \\
\hline S R 3 I B & 0 \\
\hline S R 3 I E & 3 \\
\hline 杉 板 & 3 \\
\hline コンクリートプロック & 3 \\
\hline 塩ビ鋼板 & 2 \\
\hline カラー鉄板 & 2 \\
\hline 針葉樹合板 & 3 \\
\hline 石綿スレート & 2 \\
\hline
\end{tabular}

表一6 屋外暴露試験で発生した藻類の種類

\begin{tabular}{|c|c|c|}
\hline $\begin{array}{l}\text { 略 号 } \\
\text { 名 称末太は }\end{array}$ & 部位 & 発生した桬類の種穎 \\
\hline \multirow[t]{2}{*}{$\mathrm{E} 0 \mathrm{R} 2 \mathrm{~K}$} & 中央部 & Protococcus Viridis Agardh \\
\hline & 下端部 & $\begin{array}{l}\text { Calothrix Brauni } \\
\text { Synechococcus } \\
\text { Phormidium Foverolatum }\end{array}$ \\
\hline \multirow[t]{2}{*}{ F A R $3 \mathrm{~W}$} & 中央部 & Protococcus Viridis Agardh \\
\hline & 下端部 & Oscillatoria Subbrevis \\
\hline \multirow[t]{2}{*}{ 杉板 } & 中央部 & Protococcus Viridis Agardh \\
\hline & 下端部 & $\begin{array}{l}\text { Calothrix Brauni } \\
\text { Synechococcus } \\
\text { Oscillatoria Subbrevis } \\
\text { Phormidium Foverolatum }\end{array}$ \\
\hline \multirow[t]{2}{*}{ 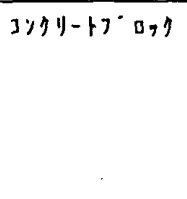 } & 中央部 & Protococcus Viridis Agardh \\
\hline & 下端部 & $\begin{array}{l}\text { Chlorococcum echinozygotum } \\
\text { Calothrix Brauni } \\
\text { oscillatoria Subbrevis } \\
\text { Phormidium foverolatum }\end{array}$ \\
\hline
\end{tabular}

部位/中央部: 武料の中央部

下端部：試料台の下伜に接している試料の端部付近

トブロックといった材質の異なる試料でも中央付近では プロトコックス属だけが発生し，水と接している時間が 非常に長い下端部では「Phormidium Foverolatum, Oscill-atoria Subbrevis：藍藻類ネンジュモ目ユレモ亜 目ユレモ科フォルミジウム属, ユレモ属」などが発生し ていた。これは前述した実際の外壁面での現象と全く同 じである。また前回に比へててらに藻類の発生期間が短 縮され，ばらつきも少なかった。したがって, 本屋外暴 露試験方法により, 比較的短期間で藻類污染を再現し外 装材料を評価することが可能であると思われる。

\section{5. 屋内促進試験}

\section{1 試験概要}

屋外暴露試験は試験規模・場所・期間などに制約があ るため，防藻㓮のスクリーニングなど外装材料の相対的 な性能比較を行う際には，より簡易的な評価方法が望ま れる。そこで，簡易評価方法を確立することを目的とし て, 藻類 ·温度 ·水分・栄養分を人為的に供給する屋内 促進試験を実施した。

\section{(1) 試 料}

試料の種類は屋外暴露試験と同じ。ただし，サイズは $50 \times 50 \mathrm{~mm}, \mathrm{~N}$ 数は 2 とした。

（2）前処理方法

経年により防藻剤が水に溶出することや紫外線のため に変質することを想定して, 恒温水槽とサンシャイン ウェザーメーターを用いて，表一7に示す 5 種類の前処 理を行った。なお，No.1の前処理はごく初期の状態を 想定して設定した。これは，屋外ではすぐに溶出する塗 料中の防倩㓮などのために，防藻剤を混入していない仕 
表一7 前処理方法

\begin{tabular}{|c|c|c|c|}
\hline No & 方法 & 温度 [ $\left.{ }^{\circ} \mathrm{C}\right]$ & 時間 [hr] \\
\hline 1 & 温水浸清 & 30 & 24 \\
\hline 2 & 温水浸清 & 60 & 240 \\
\hline 3 & 温水浸清 & 60 & 720 \\
\hline 4 & $\forall$ サシャインウェザーメーター & 63 & 150 \\
\hline 5 & 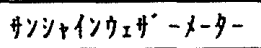 & 63 & 300 \\
\hline
\end{tabular}

上塗材でも藻類が死堿することが確認されたためであ る。

（3）屋内促進試験方法

(1) 藻類の供給：前述の外壁面加ら採取し分離・培養し たプロトコックス属の細胞を，試料に噴霧器を用い 150 万個 $/ \mathrm{cm}^{2}$ 散布した。

(2) 栄養分・水分の供給：1日 1 回噴蓩器を用い, 試料 に培養液を $2 \times 10^{-3} \mathrm{ml} / \mathrm{cm}^{2}$ 散布した。

(3) 培養: $20^{\circ} \mathrm{C}$ で 3000 ルックスの蛍光灯照射 14 時間 と暗黒 10 時間を繰り返すようにした培養室で 45 日間培 養した。

\section{2 結果および考察}

5 日ごろから徐々に試料により発育状態に差が出はじ め, 約 30 日後で増殖・死减がはっきりしてきた。

45 日後におけるプロトコックス属の増殖状態を外観 より屋外暴露武験と同様に区別し，その值を屋外暴露試 験と比較した結果を図一 3 に示す。

各試料間での藻類の発育状態の優劣は, いずれの前処 理方法においても屋外暴露試験と同様の傾向がみられ た。その中でも図一 3 に示すように屋外暴露試験 5 力月 後のランクとよく一致する前処理方法はNo.4であっ た。これに対し，No.1，2 は暴露初期に相当し全体的に ランクが小さめに, No. 3, 5 は長期間の暴露に相当しラ ンクが大きめになった。

したがって，本屋内促進試験方法により，外装材料の 相対的な性能比較が可能であると思われる。また，ある 期間有効な防藻剤でも長期間経過すれば溶出や変質など により徐々に効力がなくなると思われる。

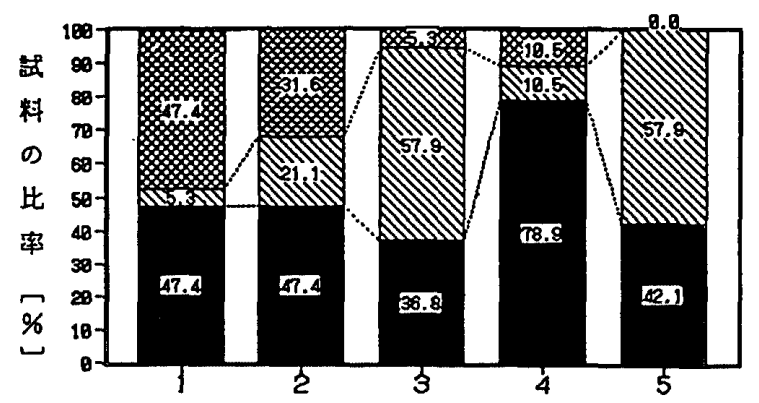

前処理方法

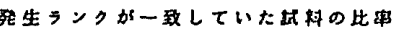

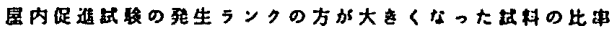
图一3 屋外暴露試験と屋内促進試験結果の比較
6. 結 論

本研究で得られた主な知見を以下に示す。

\section{（1）藻類の特定}

今回調查した範囲では，建築物の外壁面において污染 の原因となる主な藻類は緑藻類のひとつであるプロト コックス属である。ただし，水分の溜まるような部分で はフォルミジウム属などの藍藻類が污染の原因よなる。

（2）藻類污染の評価方法

(1) 水分・栄養分を霧状にして散布する屋外暴露試験方 法により，短期間で藻類污染を再現し防藻㓮の効力を含 めた外装材料の評価が可能である。

(2) 水分・栄養分と同時にプロトコックス属の細胞を散 布する屋内促進試験方法により，防藻㶡のスクリーニン グなど外壁材料の相対的な性能比較が可能である。

(3) 防藻剤の効果

防藻㓮には藻類の発生に対して大きな抑制効果がある が, 防藻㓮の種類や混入方法によりその程度が大きく異 なる。

なお，藻類の発生程度をより客観的・定量的な方法に よる物理量で表すことなどについて今後検討を進めてい く必要がある。

\section{謝 辞}

藻類の同定および屋内促進試験に際しご指導ご協力い ただきました奈良女子大学植田勝已教授をはじめ植田研 究室の方々に謝意を表します。また，まとめに際しご指 導ご助言いただきました宇都宮大学上村克郎教授および 橘高義典氏に謝意を表します。

注

1) 寒天培地として, 水 $100 \mathrm{~m} l$ 中に寒天 $1 \mathrm{~g}$, 硝酸カリウム $0.01 \mathrm{~g}$, 硫酸マグネシウム $0.005 \mathrm{~g}$ ，りん酸アンモニウム $0.005 \mathrm{~g}$ ，鉄 EDTA 液 $1 \mathrm{cc}$ を含む培地を用いた。

2）培養液として, 水 $1 l$ 中に硝酸カルシウム $0.3 \mathrm{~g}$, 硝酸力 リウム $0.2 \mathrm{~g}$, グリセロリン酸ナトリウム $0.1 \mathrm{~g}$, 硫酸マ グネシウム $0.08 \mathrm{~g}$ ，ビタミンB $120.01 \mathrm{~g}$ ，ぶどう榶 $2 \mathrm{~g}$, ペプトン $3 \mathrm{~g}$, 鉄 EDTA 液 $1 \mathrm{cc}$, トリス液 $1 \mathrm{cc}$ を含む水 溶液を用いた。

3) Protococcus Viridis Agardh は別に Pleurococcus Vulgaris Nageli, Pleurococcuss Naegelii Chodat よ゙の異 名をもつ。

4) 暴露期間における彦根地方気象台の気象デーダより求め た。

日本気像協会発行彦根地方気象台監修

滋賀県気象月報 昭和 63 年 3 月 10 月, 平成元年 4 月 9 月

\section{参考文献}

1) 仕入豊和：建築材料の耐候性（表面劣化）と維持管理に 関する調查研究, 試源 No. 220, 1985

2）仕入豊和, 地濃茂雄, 橘高義典：コンクリート壁面の污れ, セメント・コンクリートNo. 461，pp. 22 33, 1985.7

3）橘高義典：建築物外壁面の污染の調查及び基檚的考察一 
建築物外壁仕上材料の污染の評価方法に関する研究（そ の 1$)$ 一日本建築学会構造系論文報告集, 第 370 号, pp. 11 18, 1986. 12 .

4）橘高義典，上村克郎，小西敏正：屋外暴露による外壁材 料の污染一建築物外壁仕上材料の污染の評価方法に関す る研究 (その 2 ) 一日本建築学会構造系論文報告集, 第 393 号, pp. 11 17, 1988. 11

5）橘高義典：外壁仕上材料の污染の促進試験方法一建築物 外壁仕上材料の污染の評価方法に関する研究 (その 3 )一 日本建築学会構造系論文報告集, 第 404 号, pp. 15 24, 1989.10

6）大島 明：建築材料のかび抵抗性試験, 建材試験情報
Vol. 23, 1987.7

7）日本下水道事業団試験部：富栄養化防止のための指標の 開発亡実用化, 日本下水道事業団試験部報告書 No. 51004,1976

8）花田 博, 上村信夫, 野中 忠：養殖生す網の污れにつ いての一評価法, 水産增殖 Vol. 36, 1988

9) G.M. Smith : the Fresh-Water Algae of the United, McGraw-Hill Book Company, 1950

10）廣瀬弘幸ほか：日本淡水藻図鑑，内田老鶴围，1977

(1991 年 7 月 10 日原稿受理, 1992 年 1 月 8 日採用決定) 